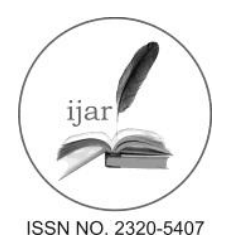

\section{Journal homepage:http://www.journalijar.com Journal DOI:10.21474/IJAR01}

\section{RESEARCH ARTICLE}

INTERNATIONAL JOURNAL

OF ADVANCED RESEARCH

(1)

\title{
Controlled Study of Application of Bee Products as New Medicine Against Breast and Lung Cancer.
}

\author{
Aly F. Mohamed ${ }^{1}$, Abir A. El-Fiky ${ }^{2}$, Osama S. Hassan ${ }^{3}$ and Nada A. El-Megharbel ${ }^{3}$. \\ 1. Head of R\&D Sector VACSERA. \\ 2. Director of ANDI COE in Antivenom Research. \\ 3. Faculty of Biotechnology, October University for Modern Science and Arts University.
}

\section{Manuscript Info Abstract}

Manuscript History:

Received: 28 April 2016

Final Accepted: 11 May 2016

Published Online: June 2016

Key words: Propolis, Bee venom, A549, MCF-7, anti-apoptotic gene, pro-apoptotic gene.

*Corresponding Author

Nada A. El-Megharbel.
Bee venom has special pharmacological activity through its complex protein structure which contains enzymes and peptides. Melittin is the bee venom's major component constituting about 50\% of its content. Recent studies showed that bee venom has a huge impact in the treatment of tumors due to synergistic antitumor effect of bee venom melittin and phospholipase A2. Propolis is a substance produced by bees from the resin collected from trees and act as an anticancer agent. The major antitumor activity of propolis depends on its main components CAPE and chrysin. This study aimed at estimating the anti-cancer potentials of Propolis, Egyptian and Georgian bee venom on breast cancer cell line MCF-7 and Lung cancer cell line A549. The Egyptian bee venom showed higher toxicity on both cells than the Georgian bee venom. After the $24 \mathrm{hr}$ treatment with Egyptian bee venom and Propolis, the results showed significance inhibitory effects on cells proliferation and induced morphological changes. The gene expression level of pro-apoptotic gene as p53 and anti-apoptotic gene as Bcl-2 were examined in both cell lines after $24 \mathrm{hr}$ of treatment. Data recorded revealed that treatment with bee venom and Propolis showed clear anticancer potentials based on the up / down regulation of pro-apoptotic and anti-apoptotic gene.

Copy Right, IJAR, 2016. All rights reserved.

\section{Introduction:-}

Bee venom has special pharmacological activity through its complex protein structure which contains enzymes and peptides.Recent studies showed that bee venom has a huge impact in the treatment of tumors (Moon etal., 2006).Melittin is the major component of bee venomconstituting about $50 \%$ of the bee venom content (Gevod\&Birdi, 1984).Melittin is an amphiphilic peptide consisting of 26 amino acid. It is isolated from honeybee Apismellifera and it's well known for its effect to disturb the membrane. It also induces structural alterations of membranes including pore formation, fusion, and vesicle formation (Leuschner\& Hansel, 2004). Phospholipase A2 is a member of the phospholipases A2 (PLA2) family of enzymes. The main activity of sPLA2 is to catalytically digest cell membrane components and thus disrupts the integrity of the lipid bilayers making cells liable to more degradation. Direct protein interaction of PLA2 enzymes with cell surface receptors regulates a range of biological activities including proliferation (Murakami et al., 1997).PLA $\mathrm{P}_{2}$ and melittin act synergistically, breaking up membranes of susceptible cells and enhancing their cytotoxic effect. This might be the main reason of the cytotoxicity of mellitin against several types of cancer cell. PLA2 plays a main role in melittin-mediated membrane disruption through uncharacterized signal transduction mechanism (Damianoglouet al., 2010).Apoptosis is the main target for the anti-cancer property of bee venom. Apoptosis is induced by bee venom in A549 cell line based on two strategies either intrinsic pathway through mitochondria mediated death signaling cascade and the release of cytochrome $\mathrm{C}$ activating caspase 9 and 3 or extrinsic pathway depending on receptor binding ligand as death receptors (DR) leading to apoptosis in A549 (Jang \& Song, 2013).Bee venom also has an anti-proliferative effect on MCF-7 cell line via the extrinsic apoptotic signaling Fas receptor. Bee venom also induced the apoptosis in breast 
cancer cell line MCF-7 through intrinsic apoptotic signaling by increasing in the mitochondrial membrane permeability and release of cytochrome C, SMAC and apoptosis inducing factor (AIF) (Ipet al., 2008).Propolis is a substance produced by bees from the resin collected from trees. Propolis ethanolic or water soluble extract and its main components have been used as an anticancer agent (Marcucci, 1995). Propolis exerts an anticancer effect via mechanism in inducing apoptosis independent of the kind of cancer. However, it is dependent on the concentration of the main natural active compounds of propolis on the cancer cells mainly Caffeic acid ph 1enethyl ester (CAPE) and chrysin (Sawickaet al, 2012). Propolis exerts an antitumor effect on A549 cell line due to the presence of its active compound chrysinvia activation of caspase 3 and 9. This effect is accompanied by downregulation of Bcl-2 gene expression (anti-apoptotic) and upregulation of Baxgene expression (pro-apoptotic) (Samarghandianet al., 2014). Propolis also exerts an antitumor effect on MCF-7 cell line via its main component CAPE via inhibition of NF-KB. CAPE also induces the pro-apoptotic protein Bax in the cells and activated p53 transcription and p38 as p38 is required for p53 phosphorylation and activation (Watabeet al., 2004).

\section{Materials:-}

Two biological cell lines (A549 and MCF-7) were used purchased from VACSERA EGYPT. Egyptian and Georgian bee venom were purchased from VACSERA EGYPT. Propolis was purchased from Agriculture research center, Egypt. Total RNA Isolation System, Reverse Transcription System, dNTPs Mixture, Taq DNA polymerase, BenchTop 1kb DNA Ladder and DNA loading buffer were all from Promega. 3-(4, 5-Dimethylthiazol-2- yl)-2, 5diphenyltetrazolium bromide (MTT) and RPMI media were purchased from Sigma-Aldrich.

\section{Methods:-}

Propolis tincture was prepared by adding $30 \mathrm{gm}$ of propolis to $70 \mathrm{ml}$ alcohol and stored for 14 days in dark cool place. Bee venom (Egyptian and Georgian) were prepared by diluting $2 \mathrm{mg}$ of bee venom in $1 \mathrm{ml}$ PBS. Maintenance of cell lineswasperformedfollowed by cell counting according to Solimanetal., 2013. Cytotoxicity Assay of Egyptian and Georgian bee venom and propolis using MTT were done and Morphologic observation was observed followed by measuring the IC50 dose.In vitro application of bee venom and propolis on MCF-7 and A549 cell lines according to Solimanetal., (2013) was done. Treated MCF-7 and A549 cells with Egyptian and Georgian bee venom and propolis were examined for induced morphological changes. It was observed $24 \mathrm{~h}$ post treatment using an inverted phase microscope according to Solimanetal., (2013). The expression of both anti-apoptotic gene as Bcl-2 and pro-apoptotic gene as p53 were examined using PCR in both cell lines; MCF-7 and A549 post 24 hr treatment via RNA extraction followed by cDNA synthesis. Then, PCR reaction using newly synthesized cDNA template was performed. The PCR product was loaded on 1\% agarose gel according to Dinicolaet al. (2012). Band intensities were measured using gel documentation system. Primer sequences and PCR product size were described in table (1).

Table 1: Primer sequences of apoptosis related genes and internal control.

\begin{tabular}{|c|c|c|c|}
\hline Gene & Primer sequences & $\begin{array}{l}\text { Size of PCR product } \\
\text { (bp) }\end{array}$ & Reference \\
\hline \multirow[t]{2}{*}{ p53 } & F: 5`-TCA GAT CCT AGC GTC GAG CCC-3` & \multirow[t]{2}{*}{353} & \multirow{2}{*}{$\begin{array}{l}\text { Suzuiet al., } \\
(2004)\end{array}$} \\
\hline & R: 5`-GGG TGT GGA ATC AAC CCA CAG-3` & & \\
\hline \multirow[t]{2}{*}{ Bcl-2 } & F: 5’-GTG AAC TGG GGG AGG ATT GT-3` & \multirow[t]{2}{*}{216} & \multirow{2}{*}{$\begin{array}{l}\text { Huang et al., } \\
(2006)\end{array}$} \\
\hline & R: 5`-GGA GAA ATC AAA CAG AGG CC-3’ & & \\
\hline \multirow[t]{2}{*}{ GAPDH } & F: 5`-CAA GGT CAT CCA TGA CAA CTT TG-3` & \multirow[t]{2}{*}{496} & \\
\hline & R: 5'-GTC CAC CAC CCT GTT GCT GTA G-3’' & & \\
\hline
\end{tabular}

\section{Statistical Analysis:-}

The obtained results were processed statistically according to Snedecor and Cochran (1982), where minimum, maximum, mean value, standard deviation, standard error, and range were presented. Comparison between groups for significance was done using $\boldsymbol{T}$. Test "Difference between two means".

\section{Results and discussion:-}

The present study aimed to estimate the anti-cancer potentials of propolis, Egyptian and Georgian bee venom via inducing apoptosis in human breast cancer MCF7 cell line and lung cancer A549 cell line. To investigate whether the propolis, Egyptian and Georgian bee venom have an anti-cancer effect, A549 and MCF-7 were treated with different concentration for $24 \mathrm{hr}$. The results showed that the treatment with the three substances reduced the cell number and viability in both cell lines that was measured using MTT assay followed by measuring the IC50 dose. 
Moreover, they induced morphological changes in that were observed by the inverted microscope.It was found that the cell shape changed from being epithelial into single small round shape. The cell viability of A549 cell lines was inversely proportional with the three substances different concentrations. Egyptian bee venom showed higher toxicity more than the Georgian on both cell lines. The MTT assay results showed that from concentration 100 to $12.5 \mu \mathrm{gm} / \mathrm{ml}$, the Georgian and Egyptian bee venom showed approximately the same A549 cell viability and nearly constant. However, propolis, at concentration $100 \mu \mathrm{gm} / \mathrm{ml}$, showed the highest cell viability (60\%); in contrast with the Egyptian and Georgian bee venom which showed low A549 cell viability (20\%) at the same concentration. In addition to the concentration approximately $6.25 \mu \mathrm{gm} / \mathrm{ml}$ the Egyptian bee venom showed low A549 cell viability about $20 \%$. However, at the same concentration the Georgian bee venom showed high cell viability about $60 \%$ (fig. 1). The inhibitory percentage was measured for the different concentrations of the Egyptian bee venom and propolis on A549 and showed a gradual decrease which confirms the anti-cancer effect of the bee venom and Propolis (Table 1, 2). In the present study, it was found that the Egyptian bee venominhibited A549 cell proliferation significantly and induced morphological changes. These dataarein agreement with the results of a study done by Jang \& Song, 2013, which confirms that the bee venom has an inhibitory effect on A549 cell line after the treatment for 24 hr.A549 cells treated with propolis for $24 \mathrm{hr}$ also showed significantgrowth inhibitory effects and induced morphological changes in a concentration and time- dependent manner. A study done by Samarghandianetal., 2014, showed that A549 cells treated with chrysin; main component of propolis; reduced concentration of Formazan crystals in MTT assay, indicating the growth inhibitory effect of propolis on the cell line in a concentration dependent manner. Therefore, the reduced cell proliferation observed in the present study may be due to the presence of chrysin in the propolis.

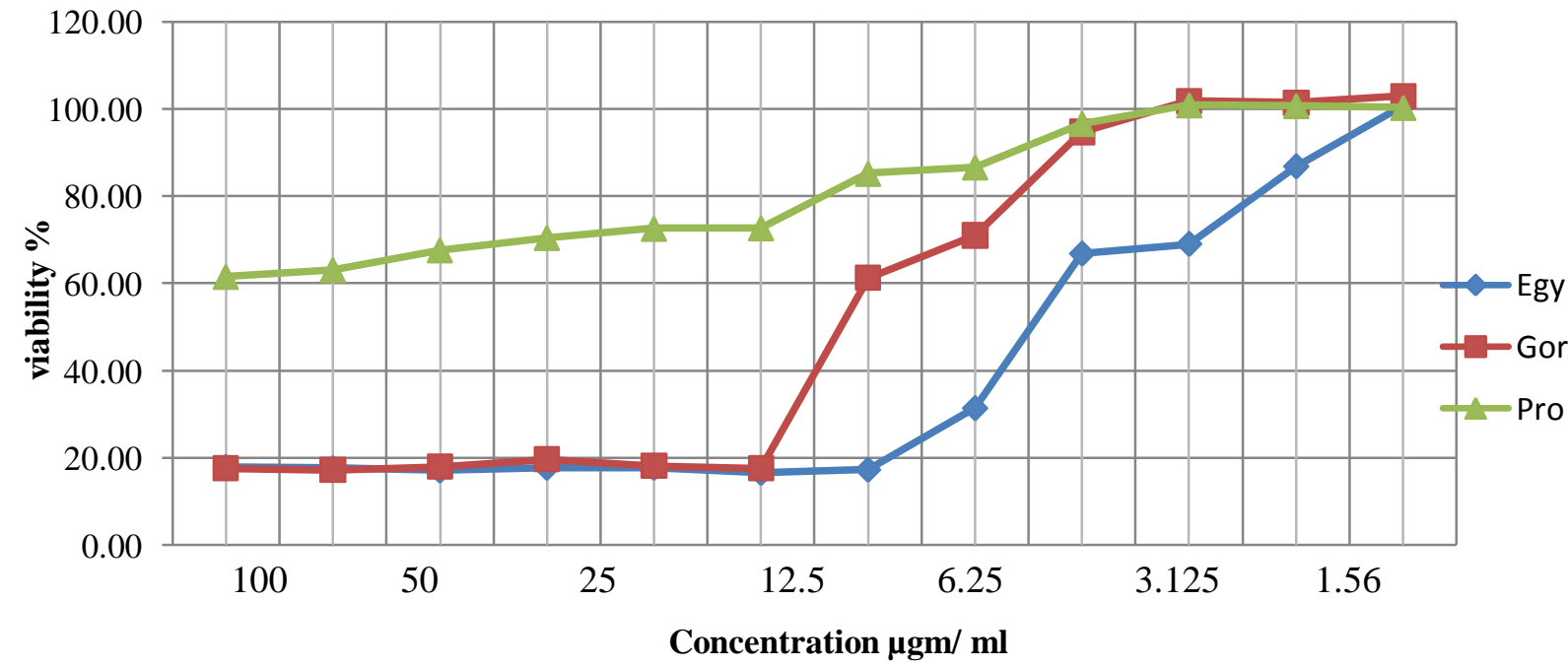

Figure 1: Evaluation of Viability \% of A-549 cell line under the effect of Egyptian and Georgian bee venom and propolis using MTT assay

Table 1: Effect of Different concentration of Egyptian bee venom and their inhibitor effect on A549 cell line 


\begin{tabular}{|l|l|l|l|}
\hline Concentrations $(\mu \mathrm{g} / \mathrm{ml})$ & Viability \% & Inhibitory \% & SD $( \pm)$ \\
\hline 100 & 17.96 & 82.04 & 0.004 \\
\hline 50 & 17.65 & 82.35 & 0.002 \\
\hline 25 & 17.12 & 82.88 & 0.002 \\
\hline 12.5 & 17.75 & 82.25 & 0.004 \\
\hline 6.25 & 17.75 & 82.25 & 0.002 \\
\hline 3.125 & 16.60 & 83.4 & 0.001 \\
\hline 1.56 & 17.33 & 82.67 & 0.002 \\
\hline 0.78 & 31.41 & 68.59 & 0.01 \\
\hline 0.39 & 66.81 & 33.19 & 0.01 \\
\hline 0.195 & 69.01 & 30.99 & 0.017 \\
\hline 0.0975 & 86.76 & 13.24 & 0.021 \\
\hline
\end{tabular}

Table 2: Effect of different concentrations of propolis and their inhibitory effect on A549 cell line

\begin{tabular}{|l|l|l|l|}
\hline Concentrations $(\mu \mathrm{g} / \mathrm{ml})$ & Viability $\%$ & Inhibitory \% & SD $( \pm)$ \\
\hline 100 & 15.13 & 84.87 & 0.001 \\
\hline 50 & 15.26 & 84.74 & 0.001 \\
\hline 25 & 15.00 & 85 & 0.001 \\
\hline 12.5 & 15.51 & 84.49 & 0.002 \\
\hline 6.25 & 18.72 & 81.28 & 0.009 \\
\hline 3.125 & 18.59 & 81.41 & 0.001 \\
\hline 1.56 & 20.51 & 79.49 & 0.01 \\
\hline 0.78 & 87.82 & 12.18 & 0.05 \\
\hline 0.39 & 98.21 & 1.79 & 0.04 \\
\hline 0.195 & 101.79 & -1.79 & 0.01 \\
\hline 0.0975 & 102.31 & -2.31 & 0.02 \\
\hline
\end{tabular}

Cytotoxicity using MTT assay was also performed for Propolis, Georgian bee venom and Egyptian bee venom on breast cancer cell line MCF-7. The cells were incubated for $24 \mathrm{hr}$ with several concentrations of the three substances. The results showed that propolis, Egyptian and Georgian bee venom induced morphological changes and inhibited cell proliferation (reducing the viable cells) in a dose and time-dependent (fig. 2). The Egyptian bee

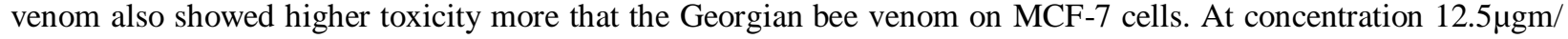
$\mathrm{ml}$, the Egyptian bee venom showed cell low cell viability about 20\%. However, at the same concentration the Georgian bee venom showed high cell viability approximately 50\% (fig. 2). Thus, these data confirm that Egyptian bee venom has high toxicity and more effect on the cells than the Georgian one. The cell proliferation inhibition and induction of morphological changes of Egyptian bee venom on MCF-7 isin agreement with the results of a study done by Ipet al, 2008, this confirms that the bee venom has an inhibitory effect on MCF-7 cell line after the treatment for $24 \mathrm{hr}$.A significant growth inhibition was also observed on the MCF-7 cells treated with propolis for $24 \mathrm{hr}$ and induced morphological changes in a concentration and time- dependent manner. A study done by Watabeet al. showed MCF-7 cells treated with Caffeic Acid Phenethyl Ester (CAPE); a main component of propolis; at several concentrations for $48 \mathrm{~h}$. Thus, the results of the present study may be attributed to the presence of CAPE in the propolis that induces the inhibition effect on the cells. 


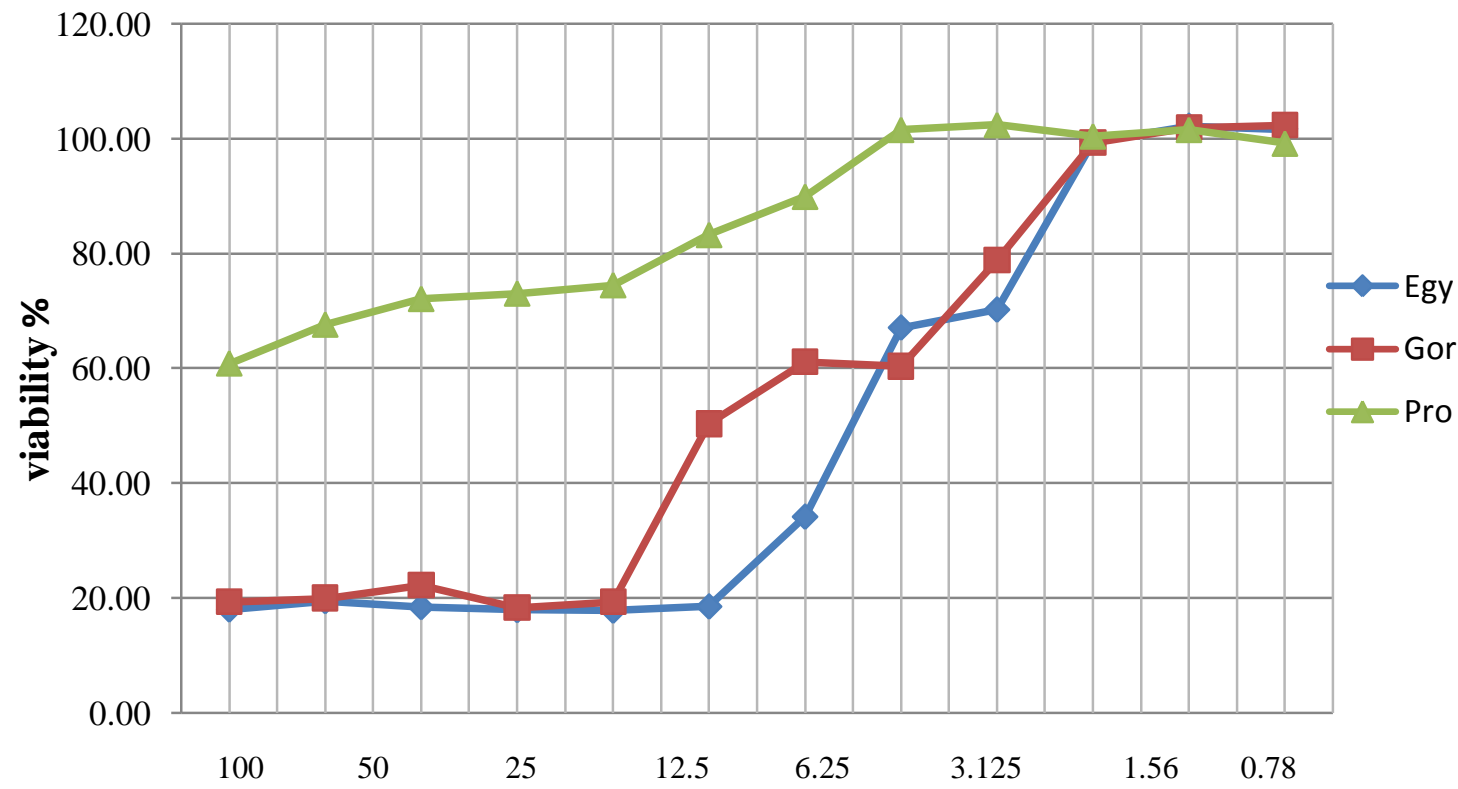

Concentraton $\mu \mathrm{gm} / \mathrm{ml}$

Figure 2: Evaluation of Viability \% of MCF7 cell line under the effect of different types of bee venom using MTT assay

Table 3: Effect of Different concentrations of Egyptian bee venom and their inhibitory effect on MCF-7 cell line

\begin{tabular}{|l|l|l|l|}
\hline Concentrations $(\mu \mathrm{g} / \mathrm{ml})$ & Viability \% & Inhibitory \% & SD $( \pm)$ \\
\hline 100 & 18.02 & 81.98 & 0.00 \\
\hline 50 & 19.48 & 80.52 & 0.01 \\
\hline 25 & 18.44 & 81.56 & 0.01 \\
\hline 12.5 & 17.92 & 82.08 & 0.00 \\
\hline 6.25 & 17.81 & 82.19 & 0.00 \\
\hline 3.125 & 18.54 & 81.46 & 0.00 \\
\hline 1.56 & 34.17 & 65.83 & 0.01 \\
\hline 0.78 & 67.08 & 32.92 & 0.01 \\
\hline 0.39 & 70.21 & 29.79 & 0.01 \\
\hline 0.195 & 99.48 & 0.52 & 0.02 \\
\hline 0.0975 & 102.19 & -2.19 & 0.00 \\
\hline
\end{tabular}

Table 4:Effect of Different concentrations of propolis and their inhibitory effect on MCF-7 cell line

\begin{tabular}{|l|l|l|l|}
\hline Concentrations $(\mu \mathrm{g} / \mathrm{ml})$ & Viability $\%$ & Inhibitory \% & SD $( \pm)$ \\
\hline 100 & 20.03 & 79.97 & 0.017616 \\
\hline 50 & 17.47 & 82.53 & 0.010116 \\
\hline 25 & 15.73 & 84.27 & 0 \\
\hline 12.5 & 15.73 & 84.27 & 0.001 \\
\hline 6.25 & 20.83 & 79.17 & 0.008505 \\
\hline 3.125 & 19.62 & 89.38 & 0.004933 \\
\hline 1.56 & 20.16 & 79.84 & 0.005 \\
\hline 0.78 & 27.96 & 72.04 & 0.022279 \\
\hline 0.39 & 55.11 & 44.89 & 0.016258 \\
\hline 0.195 & 100.13 & -0.13 & 0.041199 \\
\hline 0.0975 & 101.41 & -1.41 & 0.023335 \\
\hline
\end{tabular}


The IC50 of propolis, Egyptian and Georgian bee venom was measured via Master Plex software for both cell lines (fig. 3, 4). Regarding the results of the IC50 for Egyptian bee venom and Propolis on A549 cell line, it was recorded with a value $3.71 \mu \mathrm{g} / \mathrm{ml}$ and $11.6 \mu \mathrm{g} / \mathrm{ml}$ respectively. The value was found to be $2.91 \mu \mathrm{g} / \mathrm{ml} \mathrm{regarding} \mathrm{the} \mathrm{bee} \mathrm{venom}$ in a study done by Jang \& Song, 2013. This value is approximately near to the value of our study $(3.71 \mu \mathrm{g} / \mathrm{ml})$. However, a study carried out by Samarghandianet al., 2014, showed the effect of treating lung cancer A549 cell line for 48 and $72 \mathrm{hr}$ with chrysin; a main component of propolis. Their IC50 dose was determined to be $49.2 \pm 0.6$ and $38.7 \pm 0.8 \mu \mathrm{M}$ at 48 and $72 \mathrm{~h}$, respectively. MCF-7 cell line treated with several concentrations of Egyptian bee venom and Propolis, recorded an IC50 with a value $9.44 \mu \mathrm{g} / \mathrm{ml}$ and $4.2 \mu \mathrm{g} / \mathrm{ml}$ respectively. The IC50 value for bee venom on MCF-7 was found to be $10 \mu \mathrm{g} / \mathrm{ml}$ in a study done by Ipet al, 2008. Both studies are in agreement as the two values are nearly the same. However, a study performed by Watabeet al., 2004, showed that 48 hr treatment of MCF-7 cell line with Caffeic Acid Phenethyl Ester (CAPE); a main component of propolis; recorded an IC50 with value $10 \mu \mathrm{g} / \mathrm{ml}$.

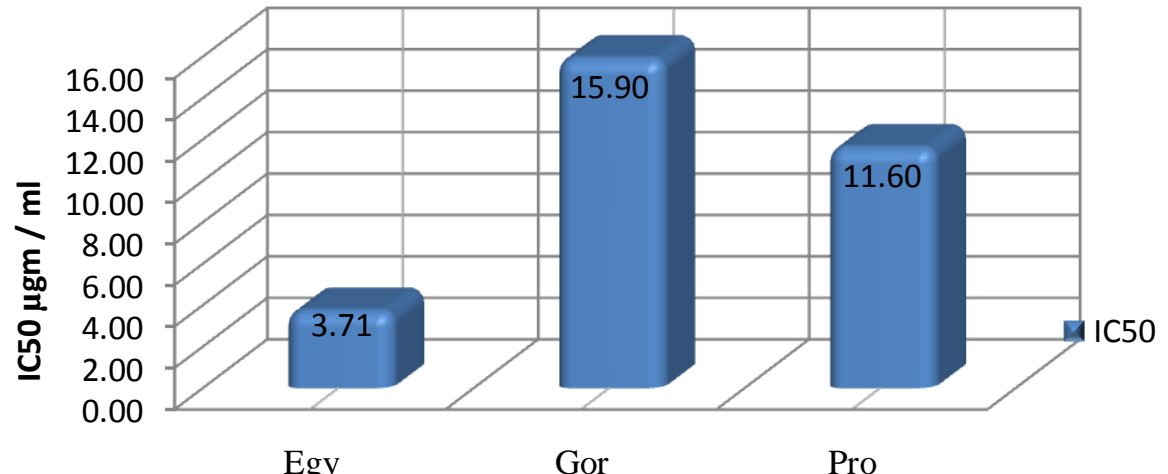

Figure 3: Evaluation of IC50 of Egyptian and Georgianbee venoms and propolis on A549 cell line

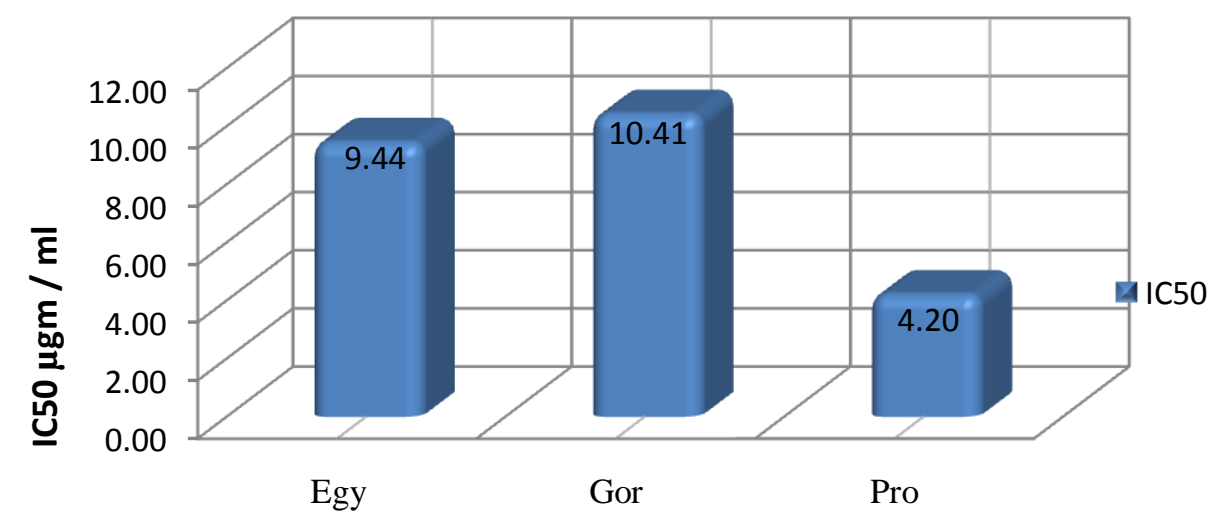

Figure 4: Evaluation of IC50 of Egyptian and Georgianbee venoms and propolis on MCF7 cell line 
Each cell line was treated for $24 \mathrm{hr}$ with IC50 dose of propolis and Egyptian bee venom and then the results were observed. The treated A549 lung cancer cell line with propolis (IC50=11.6 $\mu \mathrm{gm} / \mathrm{ml}$ )showed a significant reduction in $50 \%$ of viable cells and induced morphological changes observed by the inverted microscope compared to the control cells $(\mathrm{p} \geq 0.05)$. The cell shape became small single round cell (fig. 5). This result may be due to the presence of propolis active compound chrysin. According to a study by Samarghandianet al., it was demonstrated that chrysin activates the intrinsic caspase cascade pathway. It induces apotosis via activation of caspase 3 and 9 which in turn results in cleavage of chromatin at inter-nucleosomal sites mediated by caspase-activated DNase and degradation of DNA repair enzyme poly (ADP) ribosepolymerase (PARP) and DNA dependent protein kinase (DNA-PK); DNA-PKcs is required for the non-homologous end joining (NHEJ) pathway of DNA repair, which rejoins double-strand breaks (Samarghandianet al., 2014).Chrysin triggers apoptosis accompanied by downregulation of Bcl-2 gene expression (anti-apoptotic) and upregulation of Bax gene expression (pro-apoptotic). Once Bax is activated, it's inserted into the mitochondria causing changes in the mitochondrial membrane permeability leading to release of cytochrome $\mathrm{C}$, and activation of caspase cascade pathway that results in cell apoptosis (Samarghandianet al., 2014).The treated A549 lung cancer cell line with Egyptian bee venom (IC50= 3.71 $\mu \mathrm{gm} / \mathrm{ml}$ )showed a significant reduction in the cell viability and induced morphological changes observed by the inverted microscope compared to the control cells ( $p \geq 0.05)$. The cell shape became small single round cell (fig. 5). This indicates that Egyptian bee venom has induced apoptosis in the lung cancer cell line. This result may be due to activation of intrinsic and extrinsic pathways according to a study done by Jang \& Song (2013). Bee venom affected death receptors (DR) leading to apoptosis in A549 through the interaction with TNF cytokine family such as tumor necrosis factor (TNF) with death receptor 1 (DR1), Fas Ligand (FASL) with death receptor 1 (DR2), and Apo3 ligand (Apo3L) with death receptor 3 (DR3) (Jang \& Song, 2013).TNFR1 induces receptor trimerization and recruitment of TNFR1-associated death domain protein (TRADD), which is responsible for recruiting receptorinteracting protein 1 (RIP1), Fas-associated death domain protein (FADD), TNF-receptor-associated factor 2 (TRAF2). FADD and RIPK recruitment by TRADD results in caspase cascade activation that leads to induction of apoptosis via activation of initiator caspases caspase-2, -8 , and -10 by the activated receptor TNFR1. Initiator caspases cleave and activate effector caspases caspases-3, -6 and -7 (Baud \& Karin, 2001).Fas bind to Fas ligands (FasL) and FADD forming death-inducing signaling complex(DISC). DISC is responsible for recruiting initiator caspases as caspase 8 which in turn cleaves and activate caspase 3 and 7 to induce cell apoptosis (Jang \& Song, 2013).Apo-3 ligand will bind to the death receptor 3 resulting in induction of FADD which in turn recruit procaspase 8 . Procaspase 8 is then activated via autocatalysis resulting in active caspase 8 . Apoptosis is stimulated via activated caspase 8 through two different cascades. The first cascade is induction of apoptosis directly via cleavage and activation of caspase 3 by caspase 8 (Jang \& Song, 2013). The second cascade depends on the cleavage of Bid (a Bcl-2 family protein) by caspase 8 . Then, the truncated Bid (tBid) is translocated to mitochondria and induces the release of cytochrome $\mathrm{C}$ which activates caspase 9 and 3 and thus induces apoptosis. Mitochondrial membrane permeability that results in the release of cytochrome $\mathrm{C}$ is regulated by $\mathrm{Bax} / \mathrm{Bcl} 2$. Thus, after the release of cytochrome $\mathrm{C}$ and activation of caspase 9 and 3, the expression of apoptotic regulatory protein will increase. Anti-apoptotic Bcl2 activity will decrease while pro-apoptotic Bax expression will increase indicating that apoptosis of the cells take place (Jang \& Song, 2013).The MCF-7 cell line was incubated 24 hour with the IC50 $(4.2 \mu \mathrm{gm} / \mathrm{ml})$ of propolis. It was observed the significant reduction in cell number and viability $(\mathrm{p} \geq 0.05)$ and the induced morphological changes after the treatment (fig. 6). This indicates that the propolis induced apoptosis in the breast cancer MCF-7 cell line. This may be exterted by propolis main component Caffeic Acid Phenethyl Ester (CAPE). A study by Watabeet al. has demonstrated that CAPE induces apoptosis in MCF-7 cell line via inhibition of NF-KB. CAPE also induces the pro-apoptotic protein Bax in the cells and activated p53 transcription and p38 as p38 is required for $\mathrm{p} 53$ phosphorylation and activation (Watabeet al., 2004). The same study also suggests that CAPE leads to clustering of Fas death receptors by a Fas-L-independent mechanism and induces apoptosis (Watabeet al., 2004).Generally, CAPE induces apoptosis in MCF-7 cells via the death signal of caspase- 8 which is activated by the association of Fas with FADD that is transmitted to mitochondria via a second messenger such as Bid. Then, p38 activated by Fas aggregation acts on p53, followed by the expression of Bax, which is in turn activated by JNK that is activated by Fas aggregation. Subsequently, cytochrome c is released, caspase-9 is activated, and apoptosis is induced via caspases $(6,7)$ other than caspase-3 (Watabeet al., 2004).Regarding the MCF-7 cells treated for $24 \mathrm{hr}$ with the IC50 $(9.44 \mu \mathrm{gm} / \mathrm{ml})$ of Egyptian bee venom, it was observed the significant reduction in cell number and viability ( $\mathrm{p} \geq 0.05$ ) and the induced morphological changes after the treatment (fig. 6). This indicates that the Egyptian bee venom induced apoptosis in the breast cancer MCF-7 cell line. This may be via upregulation of Bax, p53, and p21 and downregulation of Bcl2 expression according to study done by Ipet. al, 2008.Through the extrinsic apoptotic signaling, bee venom induced apoptosis via Fas receptor. This results in the release of cytosolic proteins as Bcl-2. These proteins will target the mitochondria and change its membrane potential causing it to swell and make it 
leaky. This will lead to release of the apoptotic effector proteins in the cytosol including secondary mitochondria derived activator of caspase (SMAC) and cytochrome C (IP etal., 2008). The cytochrome C will bind to Apaf-1 and procaspase- 9 forming apoptosome which is the final irreversible stage of apoptosis. The initiator caspase-9 will activate the effector caspase-3 and induce apoptosis of the cells via damaging mutated DNA (IP et al., 2008). Bee venom also induced the apoptosis in breast cancer cell line MCF-7 through intrinsic apoptotic signaling. Irreparable DNA damage signals through p53 protein which removes the suppression of apoptosis by Bcl-2. This will leads to increase in the mitochondrial membrane permeability and release of cytochrome C, SMAC and apoptosis inducing factor (AIF). The AIF will then causes degradation of DNA and induce apoptosis (IP etal., 2008).

\section{Propolis and Egyptian bee venom induce apoptosis in A549 cell line}

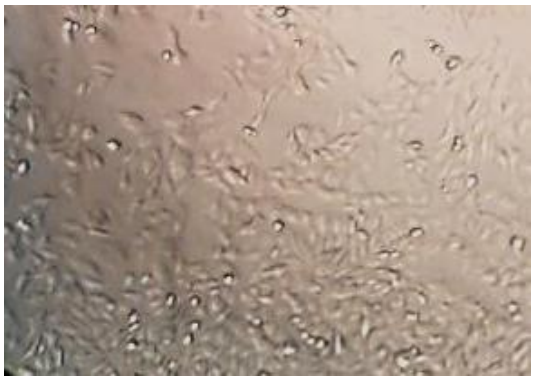

A549 Control

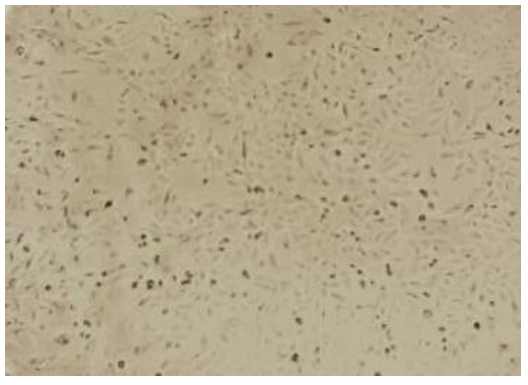

Treated A549 with 11.6 $\mu \mathrm{gm} / \mathrm{ml}$ propolis

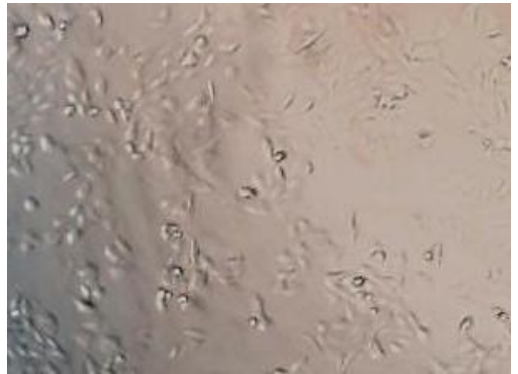

Treated A549 cells with 3.71 $\mu \mathrm{gm} / \mathrm{ml}$ Egyptian bee venom

Figure 5: Effects of Egyptian bee venom and propolis on cell viability in A549 lung cancer cells

\section{Propolis and Egyptian bee venom induce apoptosis in MCF-7 cell line}

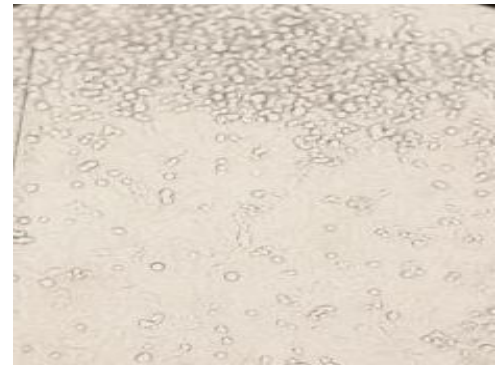

MCF-7 Control

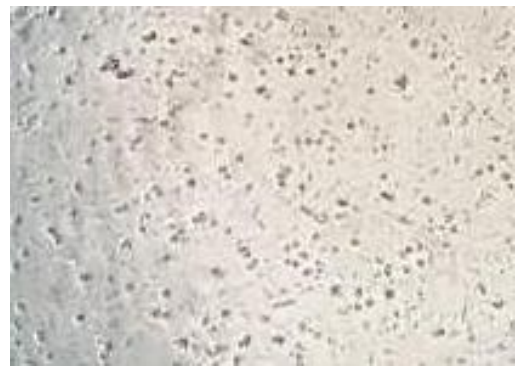

Treated MCF-7 with $4.2 \mu \mathrm{gm} / \mathrm{ml}$ propolis

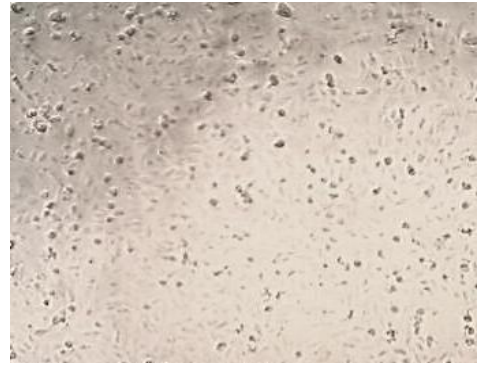

Treated MCF-7 with $9.44 \mu \mathrm{gm} / \mathrm{ml}$ bee venom

Figure 6: Effects of bee venom and propolis on cell viability in MCF-7 breast cancer cells

The expression level of pro-apoptotic gene p53 and anti-apoptotic gene Bcl-2 was measured using PCR post 24 hr treatment with propolis and Egyptian bee venom for both cell lines. Our data showed that the expression level of p53 was significantly upregulated in MCF-7 and A549 after the treatment with bee venom and Propolis. Egyptian bee venom was better effective in a significant way than Propolis on MCF7 cell line where normalization \% of P53 gene up regulation was $135 \%$ in case of bee venom while it was $122 \%$ in case of Propolis as well as in case of A549 cell line the normalization $\%$ of gene up regulation was $66 \%$ in case bee venom treatment and was $58.1 \%$ in case of propolis cell treatment.However, the Bcl-2 oncogene is downregulated in the treated MCF-7 with bee venom and Propolis after $24 \mathrm{hr}$ in a high significant manner. However, the down regulation of anti-apoptotic gene (Bcl-2) was mostly affected in case of MCF-7 treatment in a high significance way with propolis recording normalization \% of $-84 \%$ even though it was $-70 \%$ in case of MCF-7 cell treatment with bee venom. On the other hand, lung cancer cell line was mostly affected by bee venom with a high significance way more than Propolis recording 66.89 and -58.1 respectively [Table 5] and [Fig. 7]. The previous results are in agreement with a study done by Ipet 
al, 2008, which demonstrated that the p53 gene expression in treated MCF-7 is also upregulated after 24 hr treatment with bee venom and showed downregulation of Bcl-2 after the treatment. The upregulation of the tumor suppressor gene p53 and down regulation of anti-apoptotic gene Bcl-2 contributes in the induction of apoptosis.Concerning the results of MCF-7 cell treated with Propolis, a study done by Watabeetal., showed that CAPE induced the p53 activity after $24 \mathrm{hr}$ of treatment. Thus, the upregulation of p53 in our study may be due to the presence of CAPE in the used propolis.Regarding treated A549 cell line with Egyptian bee venom, these results agree with the results of a study done by Jang \& Song, 2013, that showed decrease in the expression of antiapoptotic protein Bcl-2 in a concentration dependent manner. In addition to the results of treated A549 with Propolis, a study done by Samarghandianet al., 2014, showed a reduction in the Bcl-2 mRNA expression after $48 \mathrm{hr}$ treatment with chrysin; a main component of Propolis therefore, the induced apoptosis by upregulation and downregulation gene expression in the present study may be attributed to the presence of chrysin. The previous results of the measured gene expression level indicate that the induction of apoptosis with either propolis or Egyptian bee venom treatment was related to the regulation of p53 and Bcl-2 expression level.

Table 5: Gene expression levels of p53 and Bcl-2 in treated cells compared to control cells

\begin{tabular}{|l|l|l|l|l|l|l|l|l|l|l|}
\hline Gene & $\begin{array}{l}\text { MCF7 } \\
\text { Contol }\end{array}$ & $\begin{array}{l}\text { MCF-7/ } \\
\text { BV }\end{array}$ & $\begin{array}{l}\text { Normal } \\
\%\end{array}$ & $\begin{array}{l}\text { MCF-7/ } \\
\text { Propolis }\end{array}$ & $\begin{array}{l}\text { Normal } \\
\%\end{array}$ & $\begin{array}{l}\text { A549 } \\
\text { Control }\end{array}$ & $\begin{array}{l}\text { A549/ } \\
\text { BV }\end{array}$ & $\begin{array}{l}\text { Normal } \\
\%\end{array}$ & $\begin{array}{l}\text { A549/ } \\
\text { Propolis }\end{array}$ & $\begin{array}{l}\text { Normal } \\
\%\end{array}$ \\
\hline P53 & 122 & 165 & 135 & 149 & 122 & 122 & 158 & 129 & 138 & 113.1 \\
\hline BCL-2 & 156 & 121 & -70 & 132 & -84 & 148 & 99 & -66.89 & 86 & -58.1 \\
\hline
\end{tabular}
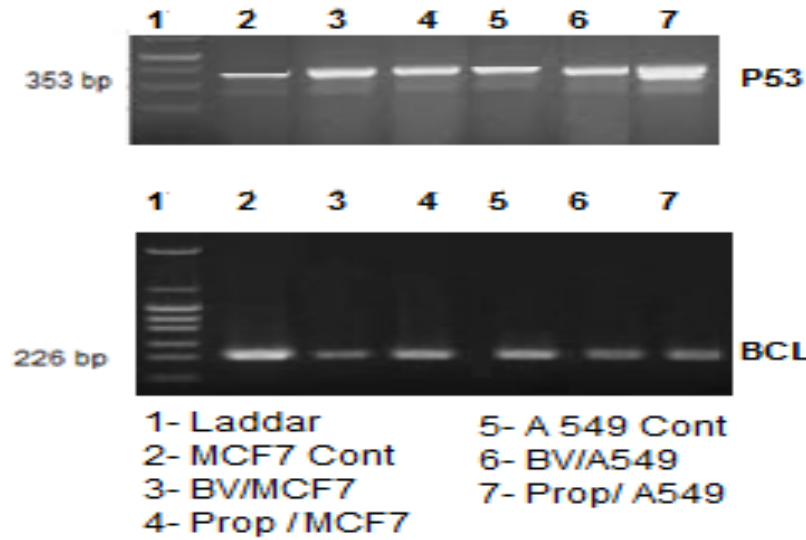

GAPDH (496 bp) $\quad$ "household control"

Figure 7: Detection of pro-apoptotic gene (p53) and anti-apoptotic gene (BCL-2) in MCF-7 and A549 cancer cell lines under the effect of bee venom and propolis using PCR 


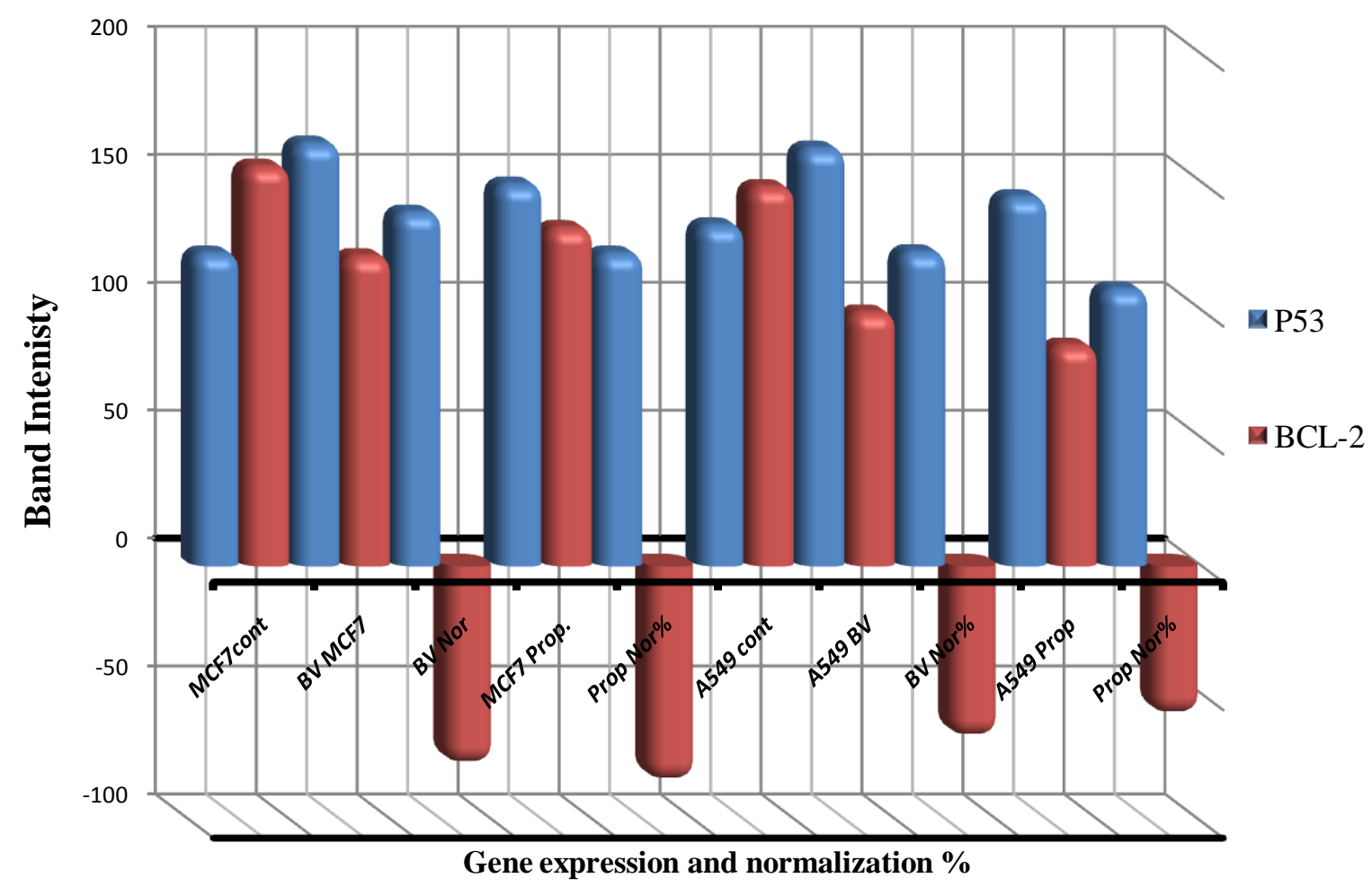

Figure 8: Evaluation of Expression profile of Pro and anti-apoptotic genes using PCR in breast and lung cancer cell lines treated with bee venom and Propolis

\section{Conclusion:-}

1- Propolis and bee venom has an anti-cancer potentials

2- Anti-cancer potentials could be confirmed by upregulation and downregulations of pro and anti-apoptotic genes

\section{Recommendations:-}

1- More cancer cell lines could be tested for verification of anti-cancer potentials of target test materials (propolis and bee venom)

2- Arranging for fractionation of bee venom and propolis for evaluation of anti-cancer potentials of different constituents.

3- In vivo application of anti-cancer potentials of tested materials using murine models.

4- Monitoring of biochemical changes pre and post treatment with anti-cancer agent regarding the antioxidant parameters (GTH, MDA, NO, ROS etc.)

\section{Acknowledgment:-}

I would like to express my sincere gratitude to my external supervisor Dr. Abir El-Fiky and Dr. Aly Fahmyand my internal supervisor Dr. Osama Saadfor their continuous support of my graduation project, their patience, motivation, and immense knowledge. I would like also to thank Prof. Ayman Diab and Prof. Dr. GehanSafwat for their effort and encouragement. 


\section{References:-}

1. Baud, V., \&Karin, M. (2001).Signal transduction by tumor necrosis factor and its relatives. Trends in cell biology. 11(9):372-7

2. Damianoglou, A., Rodger A., Pridmore C., Dafforn T.R., Mosely J.A., Sanderson J.M., and Hicks M.R. (2010). The synergistic action of melittin and phospholipase A2 with lipid membranes: Development of linear dichroism for membrane-insertion kinetics. Protein Pept.Lett. 17, 1351-1362. doi: 10.2174/0929866511009011351.

3. Dinicola, S., Cucina, A., Pasqualato, A., D’Anselmi, F., Proietti, S., Lisi, E., \&Bizzarri, M. (2012).Antiproliferative and apoptotic effects triggered by grape seed extract (GSE) versus epigallacatechin and procyanidins on colon cancer cell lines.International journal of molecular science, 13(1), 651-664

4. Gevod, V. S., \&Birdi, K. S. (1984).Melittin and the 8-26 fragment. Differences in ionophoric properties as measured by monolayer method.Journal of Biophysics, 45 (6), 1079-1083.

5. Ip, S., Liao, S., Lin, S., Lin, J., Yang, J., Lin, M., Chen, G., Lu, H., Lin, W, M., Han. S., and Chung, J.(2008). The Role of Mitochondria in Bee Venom-induced Apoptosis in Human Breast Cancer MCF7 Cells. Journal of Vivo, 22, 237-246.

6. Jang, D. M., \& Song, H. S. (2013).Inhibitory Effects of Bee Venom on Growth of A549 Lung Cancer Cells via Induction of Death Receptors. Journal of Korean Acupuncture \&Moxibustion Medicine Society, 30(1), 57-70.

7. Leuschner, C., \& Hansel, W. (2004).Membrane disrupting lytic peptides for cancer treatments.Current Pharmaceutical Desing, 10, 2299-2310.

8. Marcucci, M. C. (1995). Propolis: chemical composition, biological properties and therapeutic activity. Apidologie, 26, 88-99.

9. Murakami,M.,Nakatani,Y.,Atsumi,G.,Inoue,K.,\&Kudo,I.(1997).Regulatory functions of phospholipase A2. Critical Review in Immunology, 17(4), 225-283.

10. Moon, D. O., Park, S. Y., Heo, M. S., Kim, K. C., Park, C., \&Ko, W. S. (2006). Key regulators in bee venominduced apoptosis are Bcl-2 and caspase-3 in human leukemic U937 cells through downregulation of ERK and Akt. International Immunopharmacology, 6(12), 1796-1807.

11. Snedcor, G., W. \& Cochran, W., G. (1980).Statistical methods. $7^{\text {th }}$ Ed. Ames; Lowa state university press.

12. Sawicka, D., Car, H., Borawska, M., \&Nikliński, K. (2012). The anticancer activity of propolis.Journal of folia histochemicaetcytobiologica, 50 (1), 25-37.Doi10.5603/FHC.2012.0004

13. Soliman, E. M., Mahdy, S. E., Mosaad, W. G., Hassanin, A. I. \& El sayed, E. I. (2013). Effect of different inactivators on the efficacy of Egyptian foot and mouth disease SAT2 vaccine.Journal of animal science advances, 3(8): 391-399.

14. Samarghandian, S., Nezhad, M., and Mohammadi, G. (2014).Role of Caspases, Bax and Bcl-2 in ChrysinInduced Apoptosis in the A549 Human Lung Adenocarcinoma Epithelial Cells.Journal of Anti-Cancer Agents in Medicinal Chemistry, 14, 901-909

15. Watabe, M., Hishikawa, K., Takayanagi, A., Shimizu, N., and Nakaki, T. (2004).Caffeic Acid Phenethyl Ester Induces Apoptosis by Inhibition of NFkB and Activation of Fas in Human Breast Cancer MCF-7 Cells. Journal of biological chemistry, 279 (7), 6017-6026. Doi: 10.1074/jbc.M306040200. 